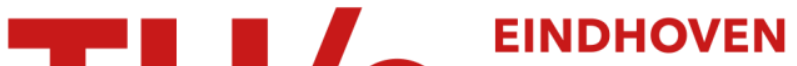 UNIVERSITY OF TECHNOLOGY
}

\section{The diffusion of carbon in non-stoichiometric carbides}

\section{Citation for published version (APA):}

Wakelkamp, W. J. J., Loo, van, F. J. J., Boelen, B., Bastin, G. F., \& Metselaar, R. (1990). The diffusion of carbon in non-stoichiometric carbides. Diffusion and Defect Data. Part A, Defect and Diffusion Forum, 66-69, 14851490. https://doi.org/10.4028/3-908044-03-0.1485

DOI:

10.4028/3-908044-03-0.1485

Document status and date:

Published: 01/01/1990

\section{Document Version:}

Publisher's PDF, also known as Version of Record (includes final page, issue and volume numbers)

\section{Please check the document version of this publication:}

- A submitted manuscript is the version of the article upon submission and before peer-review. There can be important differences between the submitted version and the official published version of record. People interested in the research are advised to contact the author for the final version of the publication, or visit the $\mathrm{DOI}$ to the publisher's website.

- The final author version and the galley proof are versions of the publication after peer review.

- The final published version features the final layout of the paper including the volume, issue and page numbers.

Link to publication

\section{General rights}

Copyright and moral rights for the publications made accessible in the public portal are retained by the authors and/or other copyright owners and it is a condition of accessing publications that users recognise and abide by the legal requirements associated with these rights.

- Users may download and print one copy of any publication from the public portal for the purpose of private study or research.

- You may not further distribute the material or use it for any profit-making activity or commercial gain

- You may freely distribute the URL identifying the publication in the public portal.

If the publication is distributed under the terms of Article 25fa of the Dutch Copyright Act, indicated by the "Taverne" license above, please follow below link for the End User Agreement:

www.tue.nl/taverne

Take down policy

If you believe that this document breaches copyright please contact us at:

openaccess@tue.nl

providing details and we will investigate your claim. 
THE DIFFUSION OF CARBON IN NON-STOICHIOMETRIC CARBIDES

\author{
W. Wakelkamp, F.J.J. van Loo, B. Boelen, G.F. Bastin \\ and R. Metselaar \\ Centre for Technical Ceramics, Laboratory of Physical Chemistry \\ Eindhoven University of Technology \\ P.O. Box 513, NL-5600 MB Eindhoven, The Netherlands
}

\title{
Introduction
}

A number of metals form monocarbides with an NaC1-type of structure, in which a sometimes large homogeneity range is present due to the occurrence of vacancies on the carbon sub-lattice[1]. It will be clear that the diffusivity will largely depend on the defect structure. A literature survey, however, reveals a great many seemingly conflicting data. In previous publications on diffusion of carbon in $\mathrm{TiC}_{1-\mathrm{y}}[2]$ and $\mathrm{ZrC}_{1-\mathrm{y}}[3]$ these discrepancies were discussed and compared with our own experimental data. In the present paper the results of experiments on the diffusion of carbon in $\mathrm{VC}_{1-\mathrm{y}}$ will be compared with those in $\mathrm{TiC}_{1-\mathrm{y}}$ and $\mathrm{ZrC}_{1-\mathrm{y}}$.

In all cases the chemical diffusion was investigated using the diffusion couple technique. Disks of pure metal and carbon, or of alloys of different composition, were joined and annealed at high temperatures for various times. By analyzing the metal and carbon concentration profiles in the reaction layer using EPMA, and measuring the position of the Kirkendall interface, the value of both the interdiffusion coefficient $\tilde{D}$ and the intrinsic diffusion coefficient $D_{C}$ were found as a function of composition. By performing these experiments at different temperatures the activation energy for diffusion could be found.

In ref.[2] the definition and calculation of the various diffusion coefficients has been discussed, a short review of which is given here. For $\mathrm{TiC}_{1-\mathrm{y}}$, for instance, the interdiffusion coefficient $\tilde{\mathrm{D}}$ and the intrinsic diffusion coefficients $D_{i}$ are related as

$$
\tilde{\mathrm{D}}=\mathrm{C}_{\mathrm{Ti}} \overline{\mathrm{V}}_{\mathrm{Ti}} \mathrm{D}_{\mathrm{C}}+\mathrm{C}_{\mathrm{C}} \overline{\mathrm{V}}_{\mathrm{C}} \mathrm{D}_{\mathrm{Ti}}
$$

where $C_{i}=$ concentration of component $i$ in moles per unit volume.

$\overline{\mathrm{V}}_{i}=$ partial molar volume of component $i$. 
In the case of $\mathrm{TiC}_{1-\mathrm{y}}$ it can be shown, that $\overrightarrow{\mathrm{V}}_{\mathrm{c}} \approx 0$, from which it follows that $C_{\mathrm{Ti}} \overline{\mathrm{V}}_{\mathrm{Ti}}$ equals one, and

$\tilde{D}=C_{\mathrm{Ti}} \bar{\nabla}_{\mathrm{Ti}} \bar{D}_{\mathrm{C}}=\mathrm{D}_{\mathrm{C}}$

The intrinsic diffusion coefficient $\mathrm{D}_{\mathrm{C}}$ is related to the tracer diffusion coefficient $D_{C}^{*}$ as:

$$
D_{C}=N_{T i} D_{C}^{*}\left(\frac{d \ln { }^{a} C}{d \ln N_{C}}\right)=\frac{D_{C}^{*}}{2-y}\left(\frac{d \ln { }^{a} C}{d \ln N_{C}}\right)
$$

where $\mathrm{N}_{\mathrm{Ti}}=$ mole fraction $\mathrm{Ti}$; $\mathrm{a}_{\mathrm{C}}=$ activity of carbon; $\mathrm{d} \ln \mathrm{a}_{\mathrm{C}} / \mathrm{d} \ln \mathrm{N}_{\mathrm{C}}=$ thermodynamic factor and $\mathrm{y}=$ composition parameter defined by the formula $\mathrm{TiC}_{1-\mathrm{y}^{*}}$

In ref.[2] it is shown, that the experimental data and the model calculations of the thermodynamic factor for e.g. $\mathrm{TiC}_{1-\mathrm{y}}$ as a function of composition and temperature show large discrepancies (see Fig. 1). We may conclude, that $D_{C}$ and $D_{C}^{*}$ as a function of composition and temperature will differ to a considerable but unknown extent. Therefore, our data on $\mathrm{D}_{\mathrm{C}}(\mathrm{y}, \mathrm{T})$ in the carbides $\mathrm{MC}_{1-\mathrm{y}}$ are very useful in describing the chemical behavior of these carbides (growth of carbide layers, layer sequence in displacement reactions[8]) but cannot be used for revealing the actual diffusion mechanism if the thermodynamic factor is not known as a function of composition and temperature.

The experimental set-up and the materials used have been described extensively in refs. [2-3].

\section{Results and Discussion}

From the measured concentration profiles $\tilde{\mathrm{D}}$ ( or $\mathrm{D}_{\mathrm{C}}$ ) for $\mathrm{TiC}_{1-\mathrm{y}}, \mathrm{ZrC}_{1-\mathrm{y}}$ and $V C_{1-y}$ were found to depend exponentially on $y$, with an activation energy $Q$ independent of $y$ as shown in Figs. $2 a-c$ and 3 . The value of $\tilde{D}(\mathrm{y}, \mathrm{T})$ can be represented by the equations: 


$$
\begin{aligned}
& \mathrm{TiC}_{1-\mathrm{y}}: \tilde{\mathrm{D}}=[0.48 \exp (9.2 \mathrm{y})] \exp -\left(\frac{39500}{\mathrm{~T}}\right) \mathrm{cm}^{2} / \mathrm{s}(0.02<\mathrm{y}<0.5) \\
& \mathrm{ZrC}_{1-\mathrm{y}}: \tilde{\mathrm{D}}=[0.0083 \exp (9.2 \mathrm{y})] \exp -\left(\frac{36600}{\mathrm{~T}}\right) \mathrm{cm}^{2} / \mathrm{s}(0.02<\mathrm{y}<0.36) \\
& \mathrm{VC}_{1-\mathrm{y}}: \tilde{\mathrm{D}}=[0.0032 \exp (15.5 \mathrm{y})] \exp -\left(\frac{28500}{\mathrm{~T}}\right) \mathrm{cm}^{2} / \mathrm{s}(0.095<\mathrm{y}<0.3)
\end{aligned}
$$

These values have to be attributed to volume diffusion in view of the very large grains in the growing carbide layers.

It must be recalled that these equations describe the value of $\tilde{D}$, related through Eqs.(1-3) with the tracer diffusion coefficient and the thermodynamic factor, which are individually dependent on $y$ and $T$ in a probably totally different way. The straight lines in Figs. 2 and 3 may, therefore, be a matter of chance rather than of fundamental necessity. It is, however, interesting to see in what way these equations can be rearranged by expressing the value of the interdiffusion coefficient $\tilde{D}$, at the composition where the maximum melting point $\mathrm{Tm}$ occurs, as a function of $\mathrm{Tm} / \mathrm{T}$. This is shown in Fig. 4, where rather arbitrarily (because of uncertainties in the phase diagrams) the compositions and corresponding maximum melting points are taken as $\mathrm{y}=0.182, \mathrm{Tm}=3067^{\circ} \mathrm{C}$ for $\mathrm{TiC}_{1-\mathrm{y}} ; \mathrm{y}=0.182, \mathrm{Tm}=3427^{\circ} \mathrm{C}$ for $\mathrm{ZrC}_{1-\mathrm{y}} ; \mathrm{y}=0.1, \mathrm{Tm}=3825^{\circ} \mathrm{C}$ for $\mathrm{TaC}_{1-\mathrm{y}}$ (from ref. [9]) and $\mathrm{y}=0.1, \mathrm{Tm}=2800^{\circ} \mathrm{C}$ for $\mathrm{VC}_{1-\mathrm{y}}$.

As can be seen, all data can be described by one straight line, expressed by the function

$$
\tilde{\mathrm{D}}=0.011 \exp -(9.06 \mathrm{Tm} / \mathrm{T}) \mathrm{cm}^{2} / \mathrm{s}
$$

This conformity may be considered as a proof for the consistence of our experimental results.

\section{References}

1. T.B. Massalski: Binary Alloy Phase Diagrams, Vo1. 1 (ASM, Metals Park OH, 1986)

2. F.J.J. van Loo and G.F. Bastin: accepted for publication in Met. Trans.

3. F.J.J. van Loo, W. Wakelkamp, G.F. Bastin and R. Metselaar: accepted for publication in Solid State Ionics

4. F. Teyssandier, M. Ducarroir and C. Bernard: Calphad 1984, 8, 233-242

5. L. Vandenbulcke: J. Electrochem. Soc. 1981, 128, 1584-87 
6. L. Vandenbulcke: Proc. 8th Int. Conf. CVD, Eds. J.M. Blocher, G.E. Vuillard and G. Wahl, the Electrochem. Soc. Pennington NY, 1981, 33-43

7. D.I. Kohlstedt, W.S. Williams and J.B. Woodhouse: J. App1. Phys. 1970, $41,4476-84$

8. F.J.J. van Loo, J.A. van Beek, G.F. Bastin and R. Metselaar: Diffusion in Solids: Recent Developments, Proc. Symp. TMS-AIME Detroit 1984, Eds. M.A. Dayananda and G.E. Murch, TMS 1985, 231-259

9. R. Resnick and L. Seigle: Trans. AIME 1966, 236, 1732-38

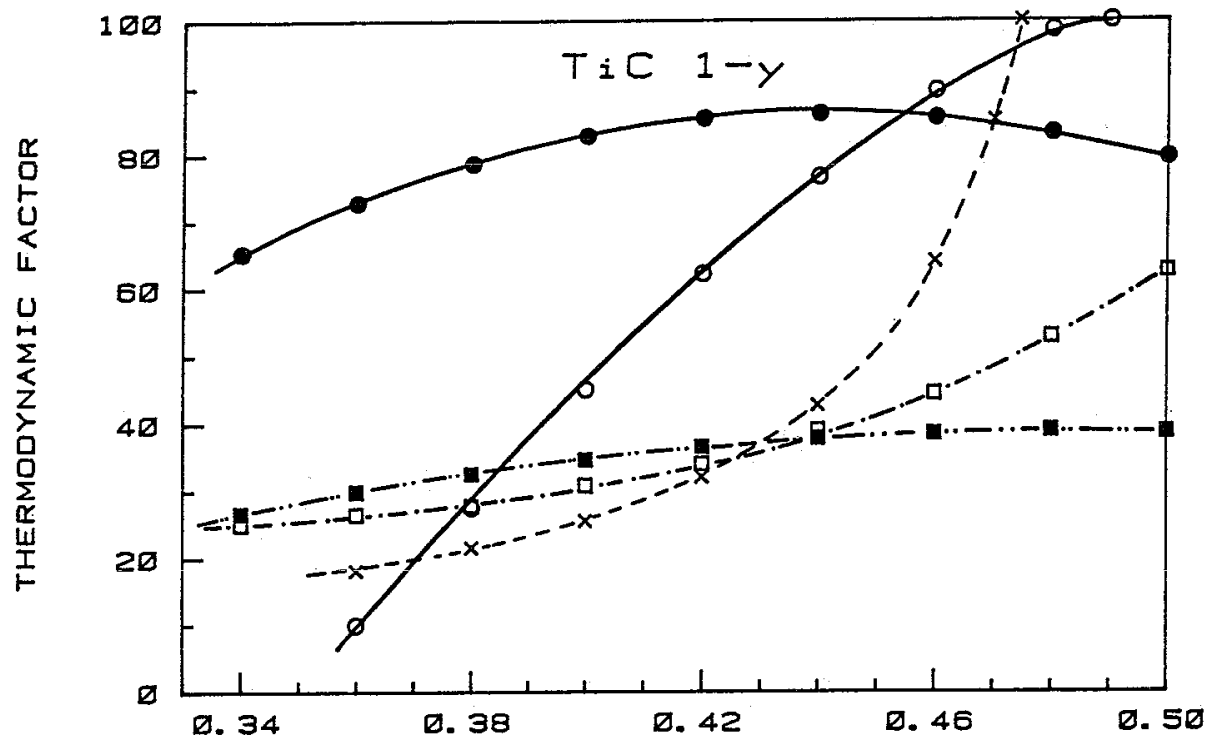

Ns

Fig. 1. The thermodynamic factor, calculated at $1300 \mathrm{~K}$ (full lines) and $1900 \mathrm{~K}$ (broken lines) according to the model developed by Teyssandier et a1. [4] $(\bullet, \mathbf{0})$, Vandenbulcke $[5,6](0, \square)$ and Kohlstedt et al. [7] ( $\mathrm{x}$, divided by $\mathrm{N}_{\mathrm{Ti}}$ in order to get the same definition). 


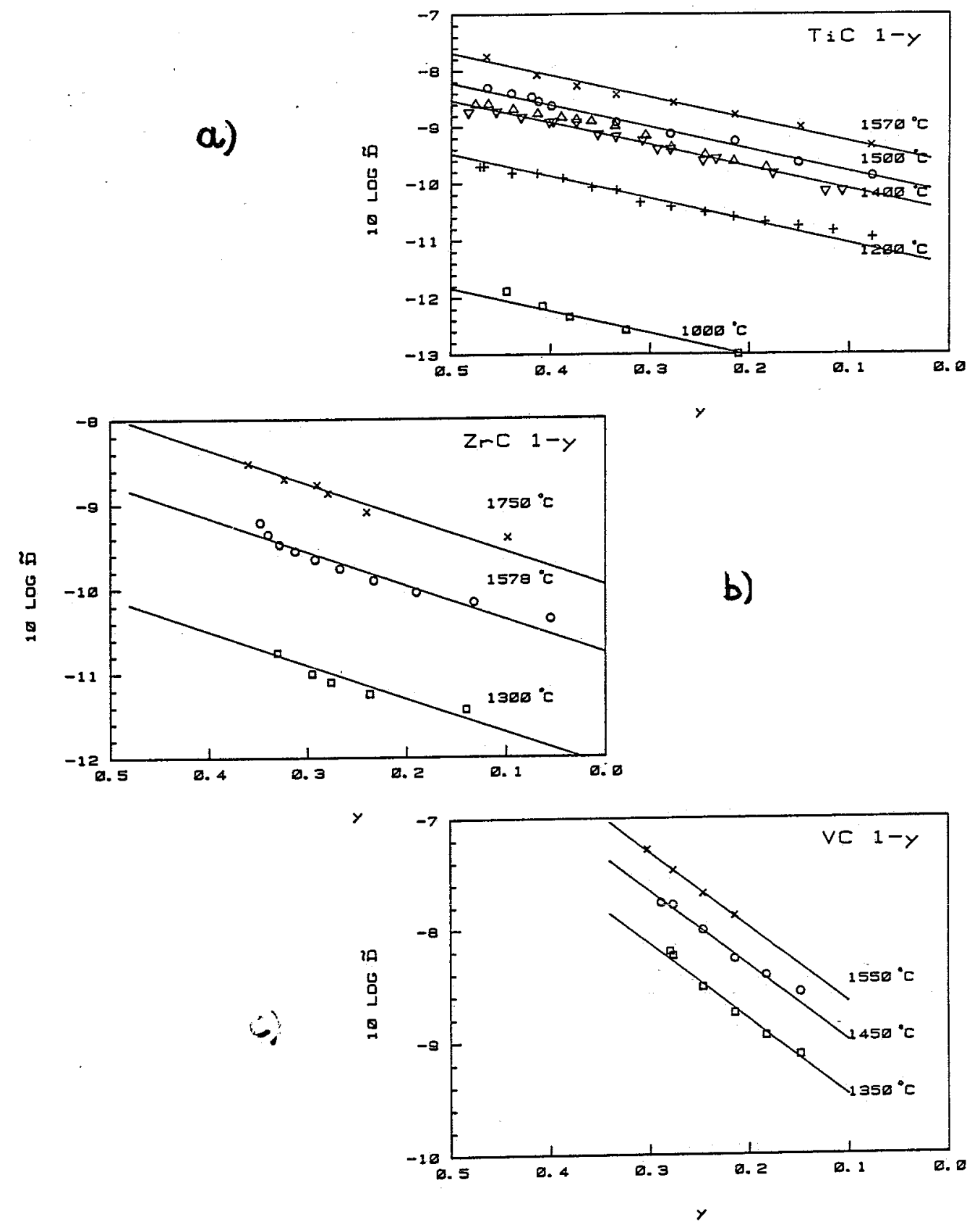

Fig. 2 a-c. Plots of $10 \log \tilde{D}\left(\mathrm{~cm}^{2} / \mathrm{s}\right)$ as a function of composition at various temperatures $\left({ }^{\circ} \mathrm{C}\right)$ for $\mathrm{TiC}_{1-\mathrm{y}}, \mathrm{ZrC}_{1-\mathrm{y}}$ and $\mathrm{VC}_{1-\mathrm{y}}$. 


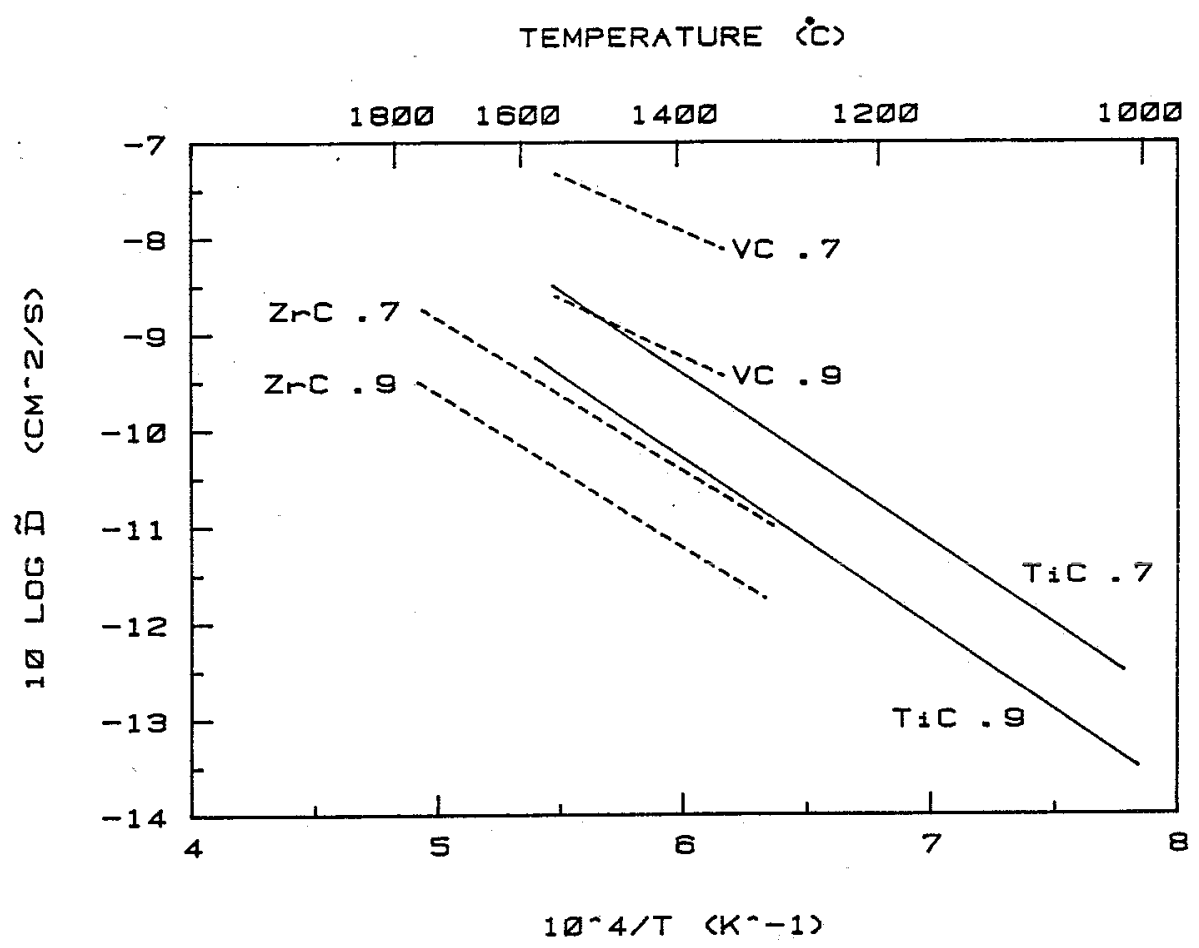

Fig. 3. Plot of $10_{10 g} \tilde{D}\left(\mathrm{~cm}^{2} / \mathrm{s}\right)$ as a function of $1 / \mathrm{T}\left(\mathrm{K}^{-1}\right)$ for $\mathrm{MC}_{0.7}$

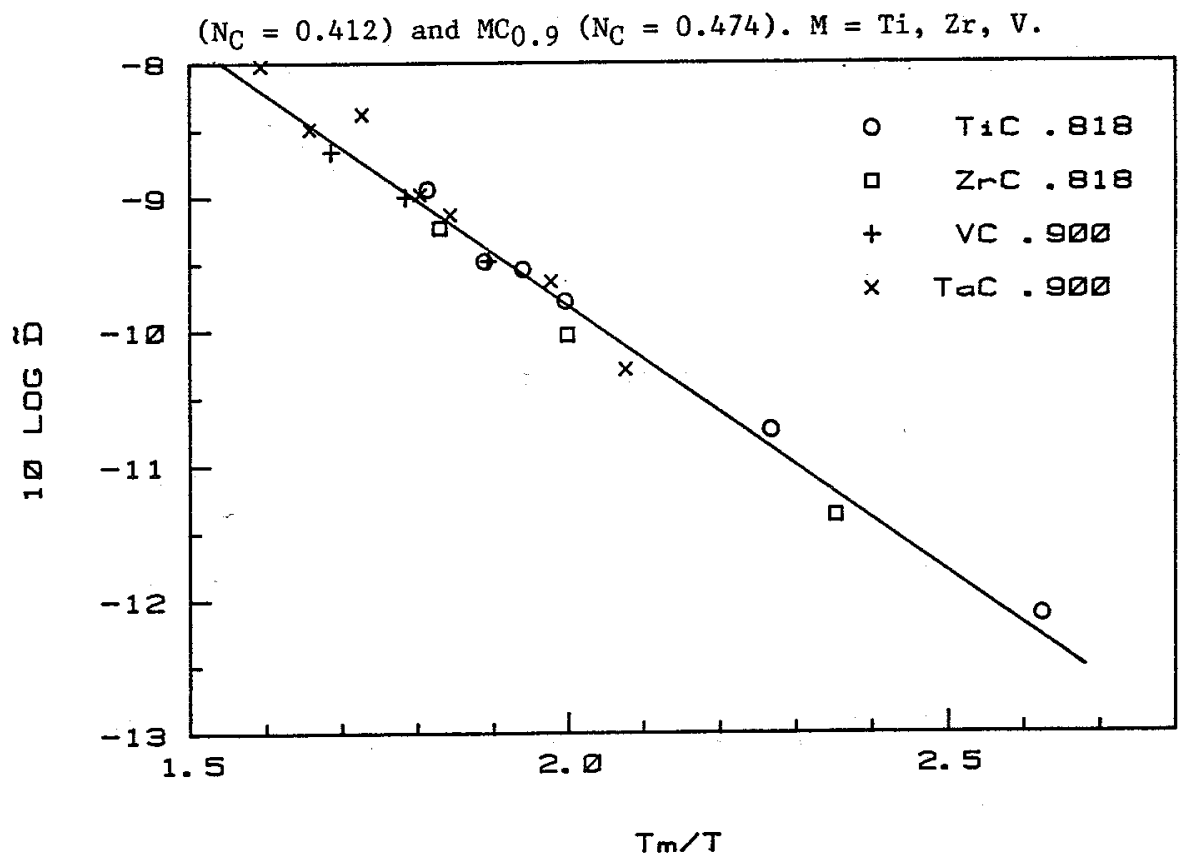

Fig. 4. Plot of $10_{10 g} \tilde{\mathrm{D}}\left(\mathrm{cm}^{2} / \mathrm{s}\right)$ for $\mathrm{TiC}_{0.818}, \mathrm{ZrC}_{0.818}, \mathrm{VC}_{0.9}$ and $\mathrm{TaC}_{0.9}[9]$ as a function of $\mathrm{Tm} / \mathrm{T}$. Tm represents the maximum melting point in the carbides. 